\title{
ILCEA
}

Revue de l'Institut des langues et cultures d'Europe, Amérique, Afrique, Asie et Australie

$31 \mid 2018$

Récits fictionnels et non fictionnels liés à des communautés professionnelles et à des groupes spécialisés

\section{How Robert Parker's 90+ and Ann Noble's Aroma Wheel Changed the Discourse of Wine Tasting Notes}

Comment la notation 90+ de Robert Parker et l'Aroma Wheel d'Ann Noble ont changé le discours des notes de dégustation du vin

\section{Andrew James}

\section{OpenEdition}

\section{Journals}

Electronic version

URL: https://journals.openedition.org/ilcea/4681

DOI: 10.4000/ilcea.4681

ISSN: 2101-0609

\section{Publisher}

UGA Éditions/Université Grenoble Alpes

\section{Printed version}

ISBN: 978-2-37747-043-3

ISSN: 1639-6073

\section{Electronic reference}

Andrew James, "How Robert Parker's 90+ and Ann Noble's Aroma Wheel Changed the Discourse of Wine Tasting Notes", ILCEA [Online], 31 | 2018, Online since 06 March 2018, connection on 02 March 2023. URL: http://journals.openedition.org/ilcea/4681 ; DOI: https://doi.org/10.4000/ilcea.4681

This text was automatically generated on 2 March 2023

All rights reserved 


\title{
How Robert Parker's 90+ and Ann Noble's Aroma Wheel Changed the Discourse of Wine Tasting Notes
}

\author{
Comment la notation 90+ de Robert Parker et l'Aroma Wheel d'Ann Noble ont \\ changé le discours des notes de dégustation du vin
}

\section{Andrew James}

\section{Introduction}

1 With the spread of quality wine to New World regions and increased competition among mid-priced products, the language used to talk about wine has seen dramatic changes over the past fifty years. Nowhere is this change more evident than in tasting notes, the two- to three-line descriptions of an individual wine's appearance, aroma and taste that feature prominently in wine magazines. This paper will examine the process by which persuasive and evaluative tasting notes came into vogue, arguing for the twin influences of Robert M. Parker, Jr., and his 100-point scale, and Ann C. Noble, the creator of an aromatic training aid called the Wine Wheel. A comparative look at Parker's tasting notes and those of Michael Broadbent, a highly respected old guard English wine critic, with reference to other critics past and present, will show that the current trend among magazine tasting note writers is to use overly precise and detailed descriptors for aromas and tastes. It is no longer sufficient to say that a Chardonnay has a citrus element without specifying whether that element is lemon, lime, grapefruit or orange. And if it happens to be orange, contemporary tasting note writers will go on to choose between bitter orange peel, orange sherbet and glazed orange slices to complete the metaphoric description. The compilation of detailed descriptors does not inevitably result in a conveying or informative tasting note, as shall be shown, but serves an entirely different purpose.

2 At the time when wine was divided into, on the one hand, fine wine, reserved for the rich and industry insiders and, on the other, low quality table wine, people did not 
need to be convinced by a tasting note to make a purchase. Now we have a vast middle region of very good wines at reasonable prices which interest the middle-classes, and a handful of wine magazines to help the confused find the best values.

Robert M. Parker, Jr., launched his magazine Wine Advocate in 1978 and Wine Spectator emerged in its present form in the following year. Prior to 1978, there were no widely circulated magazines that offered consumer ratings of wine. Parker and Broadbent-a Master of Wine who was formerly a buyer for Sotheby's-remain the two most important writers of tasting notes. Both men have authored books compiled solely of these short assessments of individual wines, and their writing styles are said to be representative of the difference between American and British ways of tasting (Robinson \& Harding, 2015). In a departure from Broadbent's style, tasting note writers in magazines today betray the influence of Parker and Noble in their reliance upon precise aroma descriptors to explain the individual components in the tasting experience. Before wine magazines came into vogue, the descriptions tended to focus on simplicity, clarity and the appreciation of wine as a holistic entity. A casual perusal of a contemporary wine magazine's tasting notes finds that in many of the thirty word reviews, roughly eight or ten wine descriptors are used, that most of them relate to aroma, and that the judgment concludes with a numerical rating. Broadbent's view of tasting, as explained in The Great Vintage Wine Book (1980), is that affixing a number is of "limited value" so he does not, nor does he employ precise aroma or taste descriptors, calling this endeavor "well-nigh an impossibility" (ibid.: 13).

Winemakers worldwide now make less cheap table wine and more mid-range products, hoping to come up with a bestselling product like the Australian Yellowtail ${ }^{1}$ or many of Californian producer Robert Mondavi's wines. With the boom in New World wines, better bottles cost less and this has everything to do with critic Parker's success in the 1980s in convincing American baby boomers that there were good values to be had from table wines all the way up to Bordeaux futures. With a sudden explosion in the population of new drinkers eager to try good wines from all over the globe, the need for a common lexis to communicate the relative merits of each product was born. When fine wine was limited to the wealthy and industry insiders, there were no scores out of a hundred and writers looked at wines as representative of particular styles and categories. Tasting language pre-Wine Advocate was a blend of common sense, idiosyncrasies and personification. A representative of traditional wine criticism, Broadbent, considers comments on style, quality and condition of more value than a precise description of aroma and taste. "If you doubt this," he wrote in 1980, "try putting into words the taste of garlic or the smell of wild thyme. Pinot smells like Pinot" (ibid.: 13). In order to understand wine, tasting experience needs to be compiled so that metaphoric descriptions of the aroma of a particular grape varietal become superfluous. The problem, however, is that for novice wine drinkers unfamiliar with the Pinot Noir grape's flavor and aroma profile, Broadbent's approach is rather unhelpful. On the other hand, an overly effusive, detailed description of the wine as velvety-smooth, luscious yet light-bodied, and redolent of violets, dried roses, chocolate mousse and, for example, raspberry pie, might make us salivate but fails to tell us whether it is a representative Pinot Noir from the Cote de Beaune region and how it measures up against its fellows.

In tasting notes we can identify a prevalent pattern in terms of language and structure. The same lexical items recur as writer takes reader (and potential consumer) through 
the tasting experience, summarizing impressions in twenty to fifty words, from the first glimpse to the aftertaste. A shared lexis and generally agreed upon means of analysis are important for any number of reasons, though the most basic one is often forgotten. Critic Jancis Robinson aptly summarizes the reasons experts and amateurs alike ought to analyze wine through clear language: '“Mmm, delicious' or even 'Urggh' will do perfectly well-if you never want to communicate with anyone else about specific wines, or if you choose not to enjoy the pleasures of comparison and monitoring that wine can offer" (2008: 33).

\section{Development of the American Market and the Rise of Parker and Noble}

6 A lot of things happened in the 1970s leading to expansion in the American wine market and the creation of contemporary winespeak, one of which was the American public's growing interest in wine due to cheaper flights to Europe. This enabled young middle-class Americans to experience and develop a taste for old World wines at the source, in addition to their native Californian wines. Around this interest grew the need for describing wines so as to guide consumers in their choice, giving rise to professional wine critics and educators such as Robert M. Parker, Jr., and Dr. Ann C. Noble.

\subsection{Robert M. Parker, Jr.: Folksy and Numerical}

7 A major turning point in the recognition of the quality of Californian wines was most certainly a blind-tasting competition held in Paris in 1976, during which Californian wines made history by defeating their French counterparts. Such were the shock waves that several members of the all-French judging panel, dismayed at discovering they had favored American wine, tried to retrieve their score cards. But the damage was done (Taber, 2005: 204) and the next edition of Time magazine announced the Judgment of Paris to the world. This competition convinced many Americans, including the young lawyer Robert M. Parker, Jr., of both the quality of homegrown wine and the importance of blind taste tests. The lesson learned was to trust one's own palate, not the label on the bottle, country of origin, or reputation of the winemaker.

8 Parker, influenced by American consumer advocate Ralph Nader's unwavering ethical stance in investigating the automobile industry, decided to implement some of Nader's methods. In the newsletter that later became the Wine Advocate, Parker offered reviews of blind-tasted wines, affixing a numerical value to each. Excellent wines received over 90 , while mediocre ones hovered in the 70s. The newsletter was successful because Americans were familiar with the 100-point scoring system from their schooldays, and Parker proved his impartiality by paying for every wine out of his own pocket and refusing free samples. He also avoided professional jargon and voiced his opinions in folksy and, at times, pejorative language, making his tasting notes entertaining and accessible to wine novices. One recurrent tasting phrase, "oodles of fruit," appeared in the review of a Napa Valley Zinfandel in the inaugural issue of the newsletter and is indicative of both his preference for wines with highly concentrated, ripe fruit and his stylistic tendency to lapse into a relaxed, colloquial tone. Initially he disdained comparisons to individual woods, fruits or flowers (McCoy, 2005), but this stance 
softened over time, perhaps because he began reviewing more exalted wines and his own wine lexis became larger and more precise.

His predilection for black and white evaluations, however, has remained unchanged. In his early reviews he once scorned a Cabernet Sauvignon for having "the finesse of a horny hippopotamus" and another with vegetal tones, calling it "a wine for the jolly green giant" (McCoy, 2005) ${ }^{2}$. His readership steadily grew until exploding after the episode of the hotly disputed 1982 Bordeaux vintage. In spite of numerous dissenting voices among more established experts and importers, Parker declared it to be the vintage of the century, a particularly daring claim when a wine has been tasted less than a year after harvesting. As events proved, he was right and suddenly, by the mid-1980s, Robert M. Parker, Jr., was the preeminent wine critic in America, if not the world. From then on, if Parker raved about a wine, sales and prices skyrocketed; conversely, a negative review could result in heavy financial losses for the winery.

Parker's effect on the style of magazine tasting notes was profound. Wine Spectator soon followed Wine Advocate's lead and introduced its own hundred point scale. Today the focus of both magazines' reviews remains firmly placed on sensory imagery and value. Typically the focus is on a wine's individual components, and after the accumulation of mouthwatering sensory descriptors, readers are reminded of its high score, affordability and approachability. The point of such reviews is not to form a holistic picture of the wine or to help readers understand its profile, but to whet their appetites and guide them towards a purchase, as illustrated by the following review of a Late Vintage Port in a recent edition of Wine Spectator:

It's filled with luscious fresh red and dark fruit flavors, plenty of spice and chocolate notes, and vibrant sweetness. At 93 points and just $\$ 25$, there's no more enticing wine if you want to learn more about Port. (Marcus, 2016)

\subsection{Ann Noble's Aroma Wine Wheel: From the General to the Particular}

11 During America's wine boom in the 1970s, Ann Noble, wine professor at the University of California, identified the need for a common tasting vocabulary to be used by people in the wine industry. In 1984 she created a Wine Wheel containing over eighty aroma descriptors. Although this may have, in part, been a reaction against the use of bombastic vocabulary in magazine tasting notes, her goal was primarily didactic. The Wine Wheel became something of a commercial success, spawning imitations and attracting attention from unknowledgeable wine drinkers and experts alike.

Previously French wine merchant André Simon, oenologist Émile Peynaud, and British auctioneer Michael Broadbent had each compiled glossaries of acceptable wine terminology that were influenced by their respective backgrounds. Their purpose was clearly to educate and inform collectors and enthusiasts who wanted to know how to appreciate wine and talk about it comprehensibly. The majority of their terms have to do with appearance, acidity, tannin, balance, mouthfeel and the aftertaste. In contrast, Noble's wheel was much more specialized in that all of the terms were devoted to that most elusive of categories: aroma. Not everyone agreed with the move towards greater specialization in discussing a wine's properties. Indeed, two of Noble's colleagues had been warning against it since the mid-1970s. A book by University of California professors Maynard Amerine and Edward Roessler entitled Wines and Their Sensory 
Evaluation (1976) allows us a glimpse of how wine language was changing even at the time. Following an extensive glossary of descriptors, such as ascetic, brilliant, and earthy, the authors pleaded with readers to use "less fanciful terms than those so often found in the popular press. Simplicity and clarity should be the initial goals, but above all the terms must have recognizable meanings with respect to the sensory evaluation of wines" (ibid.: 194). At the end of the list of approved terms, they also provided over one hundred additional descriptors to be used with caution or avoided altogether. They warned that if words like "naïve" or "empty" or "severe" must at all be used, they "should be defined as clearly as possible." Amerine and Roessler included terms such as "nutty", "chalky" and "nuance of mint" in their list of taboos because they were deemed too precise, and not immediately comprehensible. Eight years later these very terms found their way into Noble's wheel, and they are indicative of a growing preference for specialized, precise aroma descriptors over simplicity.

Noble's wheel consists of three concentric circles. In terms of the precision of the descriptors, the innermost is general and the outermost specific.

Ann C. Noble's Wine Aroma Wheel

(Partial view)

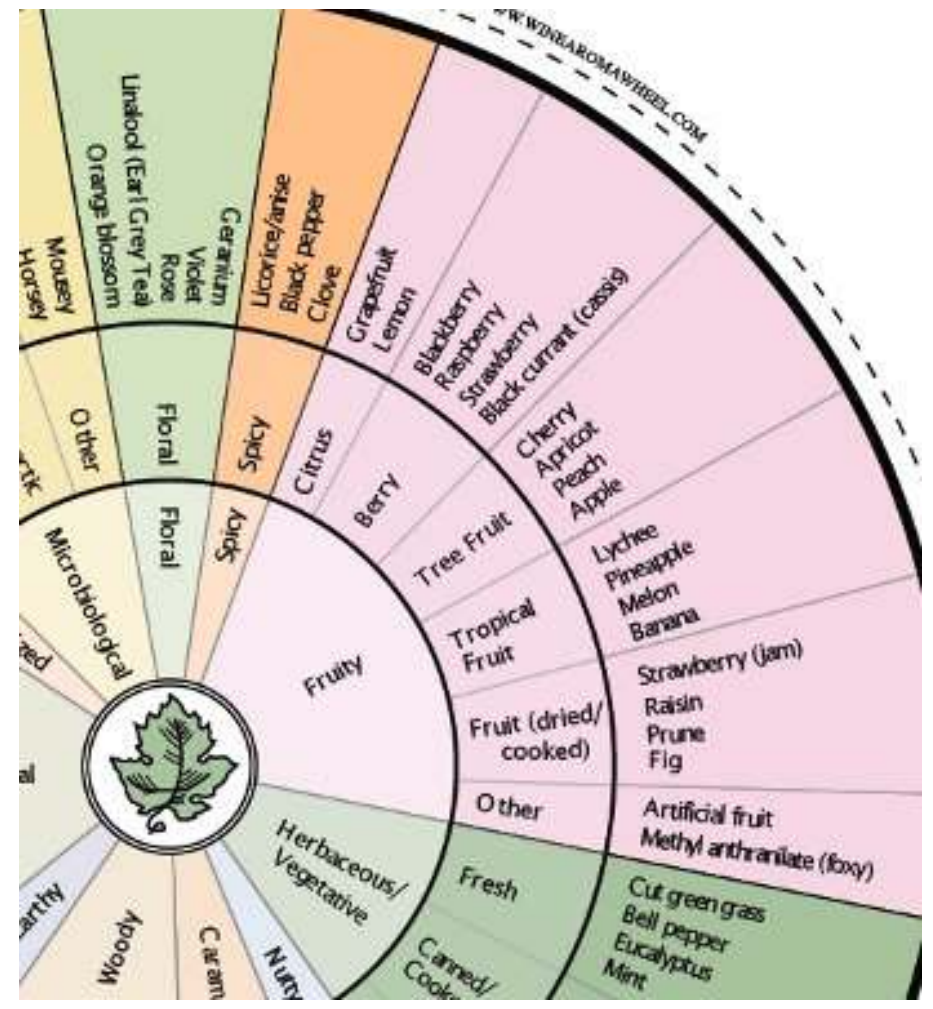

COPYRIgHT 2002 A. C. NOBLE, WWW.WINEAROMAWHEEL.COM

As mentioned before, all of the terms relate to detectable aromas. The twelve categories on the innermost circle are woody, earthy, chemical, pungent, oxidized, microbiological, floral, spicy, fruity, herbaceous or vegetative, nutty and caramel. With glass in hand, the inexperienced wine drinker uses the Wine wheel to label elusive aromatic components in the following way. If the novice sniffs and identifies, for example, something fruity, then he or she moves on to the middle circle, which presents six more possibilities: citrus, berry, tree fruit, tropical fruit, dried fruit and 
other. Should the novice decide on berry (not to be confused with tree fruit), this leads to the outermost circle, where the choices are black currant (cassis), raspberry, strawberry and blackberry. After further sniffing, he or she might then declare with authority, "This Pinot Noir has distinct notes of raspberry." It bears remembering that the reference to an aromatic component as raspberry is metaphoric, since wine does not contain berries any more than it does chalk, violets or green peppers. But when grapes are crushed, exposed to yeast and fermented, an aromatic profile far more complex than "grapey" develops. Wine that is aged in oak absorbs the vanillins present in the wood, which explains why we detect the presence of vanilla, but it can also contribute tones of nut, spice and leather, so when we use aromatic descriptors we are not talking about ingredients, but natural items with aromatic properties similar to something we detect when wine is poured into a glass.

\section{Flaws in Today's Wine Language}

In spite of their success, several problems were spawned by Parker's 100-point scale and Noble's Wine Wheel, some of which we now address briefly.

\subsection{The Hegemony of Parker}

For many wine enthusiasts, Parker turned what was largely an appreciative endeavor into an evaluative one. Rather than trying to find the overall charm of a given wine, he measured it against his palate and either passed or failed it. So great was his confidence in and reliance on his own olfactory talents that he insured his nose for a million dollars. Today it is difficult to comprehend how a single man's preferences could become the international gold standard when research continues to confirm what we have always known: like so many other physical sensations, taste and smell are highly subjective. In an attempt to explain why one taster detects a citrus note in a Chardonnay while another insists that it is apple, one research team drew upon findings in the field of phantom pain experienced by those with severed limbs, suggesting that taste and smell are not unlike pain in that they cannot be objectively quantified (Hope \& Patoine, 2009: 70). Given the subjectivity of our evaluation of aromas, instead of talking about the strawberries and black currants we find in our Pinot Noir, perhaps we should stay on the inner circle of Noble's wine wheel and limit ourselves to general remarks on red fruit.

\subsection{Merosmia or Subjective Levels of Smell Acuity}

17 Another weakness regarding Parker's approach is that although his palate is undoubtedly acute, its owner has been handicapped by his obvious bias in favor of big, oaky, fruity wines. Alice Feiring is one wine writer who has protested against the socalled "Parkerization" of wine. ${ }^{3}$ According to her, "the quest to attract Parker's attention has created wines with such concentrated power that delicacy and minerality are overpowered. And too often these wines rely on technology and additives to rack up Parker Points" (Feiring, 2008). Subsequently, in the 1980s and 1990s, the wine market was flooded with "fruit bombs", i.e., fruity wines packing a big alcoholic punch. It is interesting to consider the possibility that it is not that Parker simply dislikes 
vegetal wines and the understated mustiness of old style Rioja, but that he is physically unable to appreciate them. Wine expert Alan Young claims that individuals have different levels of smell acuity and are merosmic in that they have blind spots in regard to their perception of certain odors. He himself, for example, admits to being unable to detect nuances of mint, nut, oak and pepper, which disqualifies him from judging certain red wines. Young draws an analogy between wine and perfume when he suggests that the wide discrepancy between the odors individuals are able to detect explains the enormous variety of perfumes: if we all had the same olfactory senses, presumably there would be only a handful of fragrances on the market (Young, 2010).

\subsection{Lack of Background Knowledge}

18 If we accept the argument that the aromatic sensations we receive from wine are objectively unverifiable and can only be conveyed to others through metaphor, it is no wonder novices, who lack both a wine lexis and knowledge of varietal characteristics, struggle to relay their impressions. An Australian study (D'Alessandro \& Pecotich, 2013) found that the novice drinker's susceptibility to suggestive imagery is yet another complicating factor in the struggle to understand wine aromas. A group of novices and professionals blind-tasted twenty Shiraz/Syrah wines from China, Morocco, Australia, the United States of America and France. While the novices rated cheap French wines more highly than superior products from less prestigious wine-producing countries, the experts paid no attention to the country of origin and were able to discern which wines were of higher quality (2013). Even a supertaster-a person with an extremely acute palate-cannot apply his or her skills to wine tasting without the benefit of background knowledge and extensive tasting experience. An intriguing 2006 wine study found that experts have just as much difficulty as novices in isolating and identifying individual flavors and odors in mixtures. The participants sampled liquid mixtures with various combinations of sweet, salty and sour tastes and cinnamon, grass and nail polish remover smells. When more than two elements were combined, the participants struggled to determine which ones were present; significantly, a four component concoction dropped the success rate to the level of chance, with no discernible difference between the experts and the novices (Marshall et al., 2006). While most wine does in fact contain only a single ingredient, its complexity nevertheless increases with each of the four stages in the progression from vine to glass: as grapes are crushed, acted on by yeast, fermented, then aged in barrels and bottles, it becomes more and more difficult to isolate and identify the aromas that everyone will agree upon. While this discussion of the subjectivity of wine tasting is not a direct criticism of Parker and Noble, whose contributions to wine appreciation are enormous, the hegemony of Parker's palate and the over-reliance upon learning aids like the Wine Wheel have had the negative effect of encouraging judgmental and compartmentalized interpretations of wine.

\subsection{Overly Precise Descriptors}

Even though research tells us that the identification of individual aroma components is an imprecise art, the preference of contemporary tasting note writers for overly precise descriptors suggests just the opposite. The metaphoric use of specific fruits, flowers, spices and vegetables in tasting notes may be an attempt to stimulate the 
reader's appetite or to convey a sense of luxury-peach compote is fancier than peach! -but it also speaks to the influence exerted by the concentric circles of Noble's wine wheel. The use of this as a training aid has encouraged the misplaced view that professional tasters can pinpoint very precise aromas. While a novice may be able to identify a citrus aroma, it is the province of the expert to identify lemon zest. In this context it is worth mentioning that Bordeaux oenologist Émile Peynaud considered autosuggestion to be one of the problems plaguing professional tasters, who typically memorize long lists of acceptable descriptors for different varietals. After having identified one of the items on the list, they may then convince themselves that its usual associates must also be present. Peynaud warned tasters not to exceed "the limits of sincerity" in utilizing accepted catalogues and lists, but to trust their own impressions (1983: 253). There is little doubt that the influence of Parker and Noble has contributed to an increasing reliance upon autosuggestion in magazine tasting notes. In order for critics to be definitive in their evaluations, they need to convince the reader of the sensitivity of their palates. Uninformed readers are more likely to be convinced if, instead of writing citrus, the critic chooses lemon, lime and grapefruit.

\subsection{The Role of Memory}

20 In spite of rumors to the contrary, wine experts are not blessed with infallible olfactory and gustatory memories. A 2016 Dutch study of the role of memory in wine description revealed that experts were no better than novices at remembering general odors, such as, for example, household cleaners. However, the experts did prove to be better at remembering wine odors and more consistent and accurate in describing wines and wine-related smells. The study's authors suggest that consistency is a function of the training experts undergo to identify and name the aromatic components in wine (Croijmans \& Majid, 2016: 4). In other words, experts also have to work at remembering just like everyone else. They must rely on knowledge stored in long-term memory to identify aromatic and flavor components, and because novices do not possess such knowledge they tend to come up with fanciful non-standard expressions (Hughson \& Boakes, 2006). One American wine critic recalled attending a wine tasting before he became an initiate, and being shocked to hear the experts "describing fine wines as smelling like wet dog, nail-polish remover and sweaty socks. My writer's mind immediately snapped to attention. I can do this, too, I thought. 'Well, I get old running shoe,' I blurted, 'with a bit of raw baloney and whiteout fluid!' He soon learned that rules do in fact govern wine appreciation. Not all impressions are considered equal, let alone valid (Gregutt, 2003). This aspect of wine tasting remains unchanged. As two of the more respected English wine critics, Hugh Johnson and Jancis Robinson, put it:

Experienced tasters often rely on the immediate reaction of their memory to the first sniff of a wine. If they cannot relate it straight away to wines they have tasted in the past they must fall back on their powers of analysis. (2013: 40)

21 However, contemporary tasting notes tend to be less analytical with reference to previous vintages or comparable products. The primary function of memory today seems to be to allow the writer access to sets of memorized aroma and taste descriptors for each variety of wine. 


\section{Back to the Classics: Broadbent's Holistic Approach} like Broadbent focused on the typicality of a wine as a measure of its worth. In the hundreds of tasting notes in Broadbent's book on vintage wine, there are only a handful of references to individual berry fruits or flowers. The writing itself is like a fine wine in its austerity, restraint and depth. Words are chosen to convey rather than impress. In the following review of the 1978 Chateau Latour, a 1st growth Bordeaux, tasted after only one year of aging, note the linguistic clarity and absence of hyperbole:

Very much what one would expect from a youthful Latour of this class of vintage: opaque; dumb, that is to say closed up, with some pretty concentrated Cabernet underneath, peppery-a combination of high alcoholic content and immature component parts like vital tannin and acidity (all this on the nose); medium dry, a touch of sweetness on entry, intense, concentrated, with dry tannic finish. Quite unready as a drink but all the signals set for a good future mouthful. (1980:161)

Broadbent adheres to Amerine and Roessler's advice in explaining what "dumb" means as a wine term and the source of the peppery aroma. In contrast, Parker's 1993 review of the same wine relies heavily on precise aromatic descriptors:

Fully mature, this is one of the finest wines of the 1978 vintage. The wine's dark garnet color is followed by a bouquet offering Latour's classic aromas of pepper, herb, minerals, walnuts, and cassis. I also noted a roasted, meaty scent intertwined with the vintage's herbaceousness. Full-bodied and corpulent, this rich, concentrated, soft wine is ideal for drinking over the next 10 years. (Parker, review of Chateau Latour 1978, 1993)

Including "herbaceousness", Parker offers seven aroma descriptors to Broadbent's one ("peppery"). His score of 92 is lower than one might expect for one of the world's greatest wines, though indicative of habitual bias against wines with a vegetal component. In Parker's 2003 guide to Bordeaux he would decry the "annoyingly vegetal, herbaceous taste" of the vintage (1980).

A point that should be stressed here is that a higher degree of specificity in wine aroma descriptors is not always conveying, as the next two tasting notes for sparkling wines in the 2016 Wine Spectator prove. The first wine is described as "laser-focused and sleek with lemon, crème brûlée and mineral notes", while the second is "impeccably focused and elegant with lemon zest and crushed stone notes" (Fish, 2016). Aside from the difference of crème brûlée and a price tag of $\$ 100$ for the first and $\$ 65$ for the second, they both have good concentration, are sleek or elegant with lemon and mineral tones. There is no way, when talking of wine, to make a meaningful distinction between lemon and lemon zest, or mineral and crushed stones, and similarities in the two notes suggest that a formula is being followed.

While wine writers prior to the 1980s did not always mention specific fruits, flowers or vegetables, more generic terms like "plummy", "flowery" and "stalky" (a reference to the vegetal taste contributed by grape stems) were often employed to refer to a particular aroma or taste that was prominent. They did, however, talk about wood, as Broadbent reminds us when he recounts having lunch with the legendary critic André Simon, who was asked by their host to comment on the wines. According to Broadbent, Simon said that the first wine '"evoked memories of Berkshire'. A 1926 Chablis reminded him of the 'grace of the silver willow'; the 1919 Montrachet 'of the stateliness of the Italian poplar'; the 1920 Cheval Blanc 'of the magnificence of the purple beech'; 
the 1870 Lafite 'of the majesty of the Royal Oak'. But as to the brandy (an 1842 Roullet \& Delamain), 'there was no tree with its roots in common clay to be mentioned in the same breath ..." (Broadbent, 2007). This kind of comparison is conveying because it tells us something about the wine's quality, class and character through a metaphor. Jancis Robinson recalled Broadbent, at a 1986 tasting, comparing each bottle to a woman. A 1979 Chateau Petrus was Sophia Loren-someone to admire but not sleep with-and a double magnum of 1947 Cantenac-Brown brought to mind "chocolate and 'schoolgirls' uniforms"'. Robinson concludes the anecdote by reminding us that political correctness "was still in its infancy" at the time (Robinson, 1999: 183-84).

In spite of the trend towards the precise cataloguing of aroma and flavor components, the personification of wines continues, albeit in a slightly different manner. Current critics often attribute animate qualities to wine through verbs instead of allencompassing metaphoric comparisons. In Wine Spectator tasting notes for Oregon Pinot Noir wines the flavours of one "danc[e] deftly into a long and expressive finish" while another is "light on its feet" (Steiman, 2016). A 2007 study of manner-of-movement verbs in tasting notes revealed that action is now of the utmost importance. The corpus of six thousand notes taken from Wine Enthusiast, Wine Spectator and Wine Advocate found that the top two dynamic verbs in the corpus were "explode" and "burst", easily outnumbering the more pedestrian but useful "come", "start" and "emerge" (Caballero, 2007: 2101). Clearly, today's writers feel the need to make wine exciting and vibrant, whereas their predecessors sought to create a comprehensible overall image of a wine's character.

\section{Conclusions}

Although the discussion of wine is necessarily a metaphoric pursuit, most tasting note writers today do not make proper use of poetic license. Instead of helping novices to understand the character and merits of a particular wine through all-encompassing metaphoric comparisons, many writers offer only hyperbolic, non-conveying notes full of exotic, overly precise descriptors. This focus on sensory pleasure through aromatic descriptors and action verbs serves the actual purpose of encouraging readers to become consumers. Readers may be forgiven for suspecting that the pseudo-expert could not possibly have detected all of the elements in the descriptors offered for a given wine, and has fallen prey to autosuggestion. Part of the problem with regard to excessive description of the aromatic components in wine lies in an over-reliance on the Wine Wheel and descriptor lists. While Noble intended the Wheel to be used as a training aid for novices-"kindergarten for the nose," she called it (Gregutt, 2003)-it too often encourages a cheat sheet approach to wine tasting and the use of overly precise and exotic descriptors. We can also say that attempts to create a common tasting vocabulary have in part diminished the holistic appreciation of wine so that we now see fewer references to style, structure and balance in tasting notes. While Broadbent and other critics in the past tried to tell us of the merits of one particular tree and how it fit into the forest, the tendency among writers today is to forget all about the forest and focus on the size of the tree and the smell of its bark. The purpose of winespeak ought to be to facilitate communication. Wine has always been a social beverage, best enjoyed in the company of others. A recent Polish study reminds us of this fact. The authors found that when novice tasters were presented with a list of 
acceptable wine descriptors and asked to offer their own tasting notes, they did so with a greater degree of accuracy and consistency if they worked in pairs, rather than alone. By sharing impressions as they drank, the participants were able to better understand the wine and express their opinions (Zubek \& Denkiewicz, 2016). Too often in today's tasting notes simplicity and clarity are sacrificed for marketing purposes. Writers seem more interested in passing judgment on a wine, and affixing a numerical value to it than they are in trying to understand it and appreciate its virtues.

\section{BIBLIOGRAPHY}

AMERINE Maynard A. \& RoessLeR Edward B. (1976), Wines and Their Sensory Evaluation, San Francisco: W.H. Freeman.

BROADBENT Michael (1980), The Great Vintage Wine Book, New York: Alfred A. Knopf.

BROADBENT Michael (2007), “Wine writing: Cant, Kant and Can't”, Decanter, Online edition: <http:// www.decanter.com/features/michael-broadbent-column-3-247439> (24 Jan. 2017).

CABALLERo Rosario (2007), "Manner-of-motion verbs in wine description”, Journal of Pragmatics, 39, 2095-2114.

CROIJMANS Ilja \& MAJID Asifa (2016), "Language does not explain the wine-specific memory advantage of wine experts”, A. Papafragou, D. Grodner, D. Mirman, \& J. Trueswell (eds.), proceedings of the 38th Annual Meeting of the Cognitive Science Society, Austin, TX: Cognitive Science Society, 141-146, <https://mindmodeling.org/cogsci2016/papers/0037/index.html>.

FEIRING Alice (2008), The Battle for Wine and Love: How I Saved the World from Parkerization (Kindle edition), Orlando: Harcourt.

FISH Tim (2016), “It's Beginning to Look a Lot Like Bubbly”, Wine Spectator, Online edition: <http:// www.winespectator.com/blogs/show/id/54191> (22 Jan. 2017).

GREGUTT Paul (2003), "Scents and Nonsense", The Seattle Times: Pacific Northwest Magazine, Online edition: <http://o.seattletimes.nwsource.com/pacificnw/2003/0112/taste.html> (1 Jan. 2015). HOPE Jonathan \& PATOINE Pierre-Louis (2009), "Does a Glass of White Wine Taste Like a Glass of Domain Sigalas Santorini Asirtiko Athiri 2005? A Biosemiotic Approach to Wine-Tasting”, Biosemiotics, 2, 65-76.

HUGHSON Angus L. \& BOAKES Robert A. (2002), “The knowing nose: the role of knowledge in wine expertise", Food Quality and Preference, 13, 463-472.

JOHNSON Hugh \& ROBINSON Jancis (2013), The World Atlas of Wine (7th ed.), London: Mitchell Beazley. MAJID Asifa \& BURENHULT Niclas (2014), “Odors are expressible in language, so long as you speak the right language", Cognition, 130(2), 266-270, <10.1016/j.cognition.2013.11.004>.

MARCuS Kim (2015), “Two Sweeties from Portugal”, Wine Spectator, Online edition: <http:// www.winespectator.com/blogs/show/id/52376> (22 Jan. 2017). 
Mccoy Elin (2005), The Emperor of Wine: The Rise of Robert M. Parker, Jr., and the Reign of American Taste, Harper Collins e-book.

PARKER Robert M., Jr. (1993), “Tasting note for Chateau Latour 1978”, Wine Advocate, Online edition: <https://www.robertparker.com/> (3 Feb. 2017).

PARKER Robert M., Jr. (2003), Bordeaux: A Consumer's Guide to the World's Finest Wine (4th ed.), New York: Simon \& Schuster.

PEYNAUD Émile (1996), The Taste of Wine: The Art and Science of Wine Appreciation (M. Schuster, trans.) [1983], New York: John Wiley \& Sons.

ROBINSON Jancis (1999), Tasting Pleasure: Confessions of a Wine Lover, New York: Penguin.

ROBINSON Jancis (2008), How to Taste: a Guide to Enjoying Wine, New York: Simon \& Schuster.

ROBINSON Jancis \& HARDING Julia (2015), The Oxford Companion to Wine (4th ed.), Oxford: Oxford University Press.

SIMON André L. (1921), Wine and the Wine Trade, London: Sir Isaac Pitman and Sons.

STEIMAN Harvey (2016), "Ripeness in Oregon Pinot Noir", Wine Spectator, Online edition: <http:// www.winespectator.com/blogs/show/id/54062> (22 Jan. 2017).

TABER George M. (2005), Judgment of Paris: California vs. France and the Historic 1976 Paris Tasting that Revolutionized Wine, New York: Scribner.

VESETH Michael (2011), Wine Wars: The Curse of the Blue Nun, the Miracle of Two Buck Chuck, and the Revenge of the Terroirists, Lanham: Rowman \& Littlefield.

Young Alan (2010), Making Sense of Wine Tasting: Your Essential Guide to Enjoying Wine (Kindle edition, 5th ed.), San Francisco: Greenhouse.

ZUBEK Julian \& DENKIEWICZ Michal (2016), “Performance of Language-Coordinated Collective Systems: A Study of Wine Recognition and Description", Frontiers in Psychology, 7, <10.3389/fpsyg. 2016.01321> (3 Feb. 2017).

\section{NOTES}

1. See Michael Veseth's (2011) account of the success of Yellowtail. The company may have peaked in 2009, when it was responsible for one in five Australian export wine sales. He argues that the company was smart to create a decent quality product without discernible acidity or tannins. This means that people who do not really like wine because they consider it bitter or astringent will happily choose Yellowtail while unknowledgeable wine drinkers will find it suitably inoffensive (139-141). This sounds very much like the criteria for a literary bestseller.

2. The jolly green giant is a character familiar to most North Americans, representing a figure adorning the products of a food company best known for its canned and frozen peas. To say that a wine is worthy of the jolly green giant suggests that it is powerful, vegetal and lacking finesse.

3. Alice Feiring's The Battle for Wine and Love: How I Saved the World from Parkerization (2008) is, in spite of its daunting title, a helpful guide to understanding Parker's blind spots. Although Feiring at times too vehemently denies Parker's contributions to the wine world, her account of Parker's inability to see the merits in, for example, the Lopez de Heredia family's traditional Rioja shows that the imposition of one critic's preferences has had a negative effect on some winemakers. 


\section{ABSTRACTS}

This article looks at the changing styles and contents of wine tasting notes due to the influences of Michael Broadbent, Robert Parker and Ann Noble. After a brief introduction on the development of the American wine market, it goes on to evoke the differing styles and objectives of Robert Parker's and Michael Broadbent's wine tasting notes. The second part of the article discusses flaws in today's wine language related to such factors as the hegemony of Parker, merosmia, lack of background knowledge, overly precise descriptors and the role of memory, while the third part advocates a return to the Classics i.e., Broadbent's holistic approach to the description of wine aromas, before concluding, with regret, that today's tasting notes are written essentially for marketing purposes.

Cet article porte sur l'évolution du style et du contenu des notes de dégustation sous l'influence de Michael Broadbent, Robert Parker et Ann Noble. Après une brève introduction portant sur le développement du marché du vitivinicole aux États-Unis, l'auteur présente les styles et les objectifs contrastés des notes de dégustations de Robert Parker et Michael Broadbent. La deuxième partie de l'article expose ce que l'auteur perçoit comme étant les défauts des notes de dégustation aujourd'hui, qu'il lie à des facteurs aussi divers que l'hégémonie de Parker, la mérosmie, l'absence de connaissances, des descriptifs trop précis et le rôle de la mémoire. Dans une troisième partie, il prône un retour aux "classiques ", notamment l'approche holistique défendue par Broadbent, avant de constater, avec regret, que les notes de dégustation sont écrites aujourd'hui essentiellement à des fins promotionnelles.

\section{INDEX}

Mots-clés: arômes de vin, descriptifs de vin, notes de dégustation, mémoire, métaphore, Broadbent, Parker, Noble.

Keywords: wine aromas, wine descriptors, tasting notes, memory, metaphor, Broadbent, Parker, Noble.

\section{AUTHOR}

\section{ANDREW JAMES}

Associate Professor

School of Commerce, Meiji University, Tokyo (Japan) 